\title{
PEREKRUTAN DAN KEGIATAN ANAK SEBAGAI KURIR DALAM JARINGAN PEREDARAN NARKOBA
}

\author{
Anton Prasetyo \\ anton.prasetyo-2015@pasca.unair.ac.id \\ Program Studi Magister Kajian Ilmu Kepolisian Sekolah Pasca Sarjana \\ Universitas Airlangga Jln. Airlangga No.4-6 Surabaya
}

\begin{abstract}
Polrestabes satresnarkoba data for the third quarter in surabaya until 2018 in total there are 20 suspects with the drug as a courier. As many as 15 people have as users, dealers and courier 23 .So based on the advanced analysis was needed on how the recruitment of children as a courier in the trafficking of drugs and analyzes on efforts to satresnarkoba polrestabes surabaya in reducing activity the recruitment of children as drug couriers .The statute used is research approach, the conceptual approach and empirical legal using interviews as a primary data and the cases handled satresnarkoba polrestabes surabaya as secondary data. The pattern of recruitment carried out to make children as drug couriers is through the use of weak economic conditions of children and the inability of children to work so that children have no other way to get money for drugs other than being couriers. The use of child loyalty to his group colleagues, the use of trap patterns and threats is another way of recruiting children in drug syndicates. The effort to handle the recruitment of children as drug couriers by the Satresnarkoba Polrestabes Surabaya is done in a pre-emptive manner, namely through integrated coordination with BNN Surabaya City by exchanging information about children caught in drugs and drug syndicates detected. The formation of anti- drug student cadres and drug counseling for parents of students is a pre-emptive method carried out by the Satresnarkoba Polrestabes Surabaya. While the repressive method is carried out by the application of criminal procedural law, especially for drug dealers and dealers to break drug networks. Firm and measurable actions and various drug raids operations are expected to break the chain of drug trafficking, especially those targeting children to be used as couriers.
\end{abstract}

Keywords: Narcotics, Couriers, Children

\begin{abstract}
Data Satresnarkoba Polrestabes Surabaya sampai pada kwartal ketiga tahun 2018 total ada 20 orang tersangka dengan anak sebagai kurir narkoba. Dari jumlah tersebut 15 orang tetapkan sebagai pemakai, 2 pengedar dan 3 kurir. Sehingga berdasarkan hal tersebut diperlukan analisis mendalam mengenai bagaimanakah bagaimanakah perekrutan anak sebagai kurir dalam jaringan peredaran narkoba serta menganalisis tentang upaya Satresnarkoba Polrestabes Surabaya dalam menanggulangi kegiatan perekrutan anak sebagai kurir narkoba. Pendekatan penelitian yang digunakan adalah statute approach, dan conceptual approach dengan penelitian hukum empiris yang menggunakan wawancara sebagai data primer dan kasus kasus yang ditangani Satresnarkoba Polrestabes Surabaya sebagai data sekunder. Pola rekrutmen yang dilakukan untuk menjadikan anak sebagai kurir narkoba adalah melalui pemanfaatan lemahnya kondisi ekonomi anak dan ketidakmampuan anak untuk bekerja sehingga anak tidak ada jalan lain mendapatkan uang untuk narkoba selain menjadi kurir. Pemanfaatan loyanlitas anak pada rekan sekelompoknya, penggunaan pola jebakan dan ancaman merupakan cara lain dalam merekrut anak dalam sindikat narkoba. Upaya penanggulanganan perekrutan anak sebagai kurir narkoba oleh Satresnarkoba Polrestabes Surabaya dilakukan dengan cara preemtif yakni melalui koordinasi terpadu dengan BNN Kota Surabaya dengan pertukaran informasi mengenai anak yang terjerat narkoba beserta sindikat narkoba yang terdeteksi. Pembentukan kader pelajar anti narkoba serta penyuluhan narkoba pada orang tua siswa merupakan cara preemtif yang dilakukan oleh Satresnarkoba Polrestabes Surabaya. Sedangkan cara represif dilakukan dengan penerapan hukum acara pidana khususnya bagi para pengedar dan bandar narkoba untuk memuts jaringan Narkoba. Tindakan tegas dan terukur serta berbagai operasi penggerebekan narkoba diharapkan dapat memutus rantai peredaran narkoba khususnya yang menyasar anak untuk dijadikan kurir.
\end{abstract}

Kata Kunci : Narkoba, Kurir, Anak

\section{A. Pendahuluan}

Indonesia merupakan negara kepulauan terbesar di dunia dan memiliki letak geografis yang unik dan strategis. Berdasarkan hasil penelitian yang dilakukan BNN bekerjasama dengan Puslitkes-UI Tahun 2015, angka prevalensi ${ }^{1}$ penyalahgunaan narkoba di Indonesia berada 


\begin{abstract}
${ }^{1}$ Definisi operasional dari laju peningkatan prevalensi penyalahgunaan Narkoba adalah Perubahan rasio jumlah penyalahgunaan narkoba terhadap populasi penduduk yang berpotensi menyalahgunakan narkoba (usia 10-59 tahun) pada suatu tahun dibandingkan tahun sebelumnya.
\end{abstract}

dikisaran 2,20\% atau sekitar 4.098.029 orang dari total populasi penduduk Indonesia (berusia 10 - 59 tahun). Dibandingkan dengan hasil penelitian tahun 2014 mengalami peningkatan 0,02\% dari 2,18\% (2014) ke 2,20\% (2015).Lebih khusus lagi, mengenai jumlah penyalahguna narkoba di Jawa Timur Tahun 2018, saat ini dari data BNN Provinsi Jatim diketahui telah mencapai 568.304 pengguna. Jumlah tersebut merupakan yang terbanyak kedua dari seluruh provinsi di Indonesia. Dari jumlah tersebut, sebanyak 212.704 atau 37 persennya masih dalam tahap I atau coba pakai/ pernah pakai (ever used). Sedangkan 263.843 jiwa atau 46 persennya adalah dalam tahap II atau teratur pakai. Sedangkan tahap ke tiga adalah tahap pecandu non suntik mencapai 82.668 orang, dan terakhir sebanyak 9089 jiwa adalah pecandu suntik. ${ }^{2}$

Pada dasarnya, penyalahgunaan dan peredaran gelap narkoba di Indonesia dan juga di wilayah Jawa Timur tidak terlepas dari pengaruh perkembangan global pengguna narkoba yang harus ditangani secara segera dan serius sebagai salah satu bentuk perlawanan terhadap sindikat jaringan peredaran gelap narkoba. Kejahatan peredaran narkoba ini disebut sebagai suatu sindikat dan mempunyai jaringan yang luas karena rata-rata kejahatan peredaran narkoba merupakan suatu kejahatan yang terorganisir secara rapi.

Secara teoritis, kejahatan terorganisasi pada dasarnya dibagi menjadi lima ketegori tindakan kriminal yakni pertama adalah konspirasi yang merupakan karakteristik paling utama kejahatan terorganisasi karena sebelum melakukan kejahatan selalu ada perencanaan. Kedua, penyediaan barang ilegal terkait penyediaan barang curian serta penyediaan berbagai jenis narkoba. Ketiga, berupa penyediaan jasa ilegal berupa penyediaan jasa perjudian, bisnis rente dan seks atau prostitusi. Keempat adalah pemerasan yang berupa cara untuk medapatkan properti dari orang lain dengan menggunakan ancaman. Kelima berupa penipuan yang merupakan suatu kejahatan dengan maksud menggerakan orang lain untuk menyerahkan atau berbuat sesuatu dengan mempergunakan upayaupaya yang diantaranya dengan tipu muslihat. Berbeda dengan bisnis yang sah, organisasi kriminal selain terorganisir juga bersifat sangat rahasia.

Satuan tugas dalam melaksanakan pemberantasan narkoba di jajaran Polrestabes Surabaya dilaksanakan oleh Satuan Reserse Narkoba (Satresnarkoba) yang berdasarkan Pasal 47 
Satresnarkoba Polrestabes Surabaya bertanggung jawab penuh terhadap fungsinya dalam melakukan penyelidikan dan penyidikan tindak pidana penyalahgunaan dan peredaran gelap narkoba yang berada di wilayah hukumnya.

\footnotetext{
${ }^{2}$ Data BNN Provinsi Jatim 2016.

${ }^{3}$ Jay Alabnese, Kejahatan Prenadamedia Group, 2016, hal. 28
}

Terorganisasi

(Organized

Crime) Akar

dan Perkembanganannya,

Perkap Nomor 23 Tahun 2010 disebutkan bahwa Satresnarkoba merupakan unsur pelaksana tugas pokok yang berada di bawah Kapolres yang bertugas melaksanakan pembinaan fungsi penyelidikan, penyidikan, pengawasan penyidikan tindak pidana penyalahgunaan dan peredaran gelap Narkoba berikut prekursornya, serta pembinaan dan penyuluhan dalam rangka pencegahan dan rehabilitasi korban penyalahgunaan Narkoba. Sehingga profesionalisme penyidik dengan tetap berpedoman pada asas pelaksanaan tugas yang antara lain adalah : pertama, asas legalitas yakni dalam melaksanakan tugasnya sebagai penegak hukum wajib tunduk pada hukum. Kedua, asas kewajiban yang menekankan bahwa apa yang dilakukan oleh kepolisian didasarkan pada kewajiban yang diembannya, sehingga dalam menyelenggarakan tugasnya dilakukan dengan penuh keiklasan, penuh dedikasi tanpa adanya pamrih semata-mata untuk kepentingan tugas. Ketiga, Asas partisipasi yang berarti bahwa tindakan yang dilakukan kepolisian diusahakan mendapat dukungan atau partisipasi dari masyarakat, karena tugas-tugas yang diemban oleh kepolisian tidak akan dapat terwujud sesuai harapan tanpa adanya dukungan dan partisipasi dari masyarakat, yakni dalam bentuk komitmen masyarakat untuk secara aktif berpartisipasi dalam mewujudkan polisi yang mandiri, professional dan memenuhi harapan masyarakat. Keempat, asas preventif yang mana harus selalu mengedepankan tindakan pencegahan dari pada penindakan (represif) kepada masyarakat. Kelima, asas subsidiaritas yakni dalam melaksanakan tugas dan wewenangnya kepolisian mengadakan bantuan dan hubungan serta kerja sama dengan berbagai pihak baik di dalam negeri maupun di luar negeri yang bersifat fungsional.

Kelima asas tersebut harus selalu terus dikedepankan oleh setiap anggota Satresnarkoba Polrestabes Surabaya, dikarenakan kompleksnya permasalahan peredaran narkoba di Surabaya dengan beragam modus peredaran yang semakin canggih ditambah lagi karakteristik masyarakat yang beragam serta pertumbuhan ekonomi daerah Surabaya yang sangat cepat. Dengan daya tarik yang sangat besar ini para pengedar narkoba berusaha masuk ke berbagai lini kehidupan masyarakat Surabaya dan memikirkan benar modusnya agar Salah satu modus yang kerap 
digunakan saat ini adalah dengan menggunakan anak sebagai kurir narkoba. Menurut Menteri Sosial Khofifah Indar Parawansa, bandar narkoba mengetahui bahwa ada celah hukum sehingga jika anak tersangkut kasus narkoba maka anak-anak hanya bisa dikenakan Sistem Peradilan Pidana Anak dengan maksimum hukuman 10 tahun. Kemudian akan bebas bersyarat setelah menjalani setengah hukuman penjara ditambah bila dia mendapat remisi bisa hanya 3,5 tahun. Bandar mengambil kurir dari usia anak-anak karena jika kurirnya adalah anak, maka anak yang menjadi kurir tersebut tidak bisa

\footnotetext{
${ }^{4}$ Bisri Ilham, Sistem Hukum Indonesia, Grafindo Persada, Jakarta, 2004, hal. 32.
}

mendapatkan pemberatan hukuman dan maksimum hukuman adalah separuh dari maksimum hukuman orang dewasa. Dengan adanya celah ini, bandar akan masuk dalam celah regulasi dan memanfaatkan ruang dimana bandar tersebut bisa lebih meringankan bila pelaku kurir narkoba adalah anak. ${ }^{5}$ Selain itu digunakannya anak sebagai kurir narkoba dikarenakan para bandar ini berpikir anak-anak tidak akan mudah dicurigai, sehingga menggunakan jasa mereka untuk mengedarkan narkoba akan lebih mudah. ${ }^{6}$

Pola perekrutan anak-anak itu berlangsung sangat halus. Selain memanfaatkan kondisi perekonomian dan pendidikan yang rendah dari anak anak yang dijadikan kurir narkoba, sejumlah anak kurir narkoba berdasarkan data Satresnarkoba Polrestabes Surabaya mengaku bahwa mereka tidak sadar ketika sedang dijebak dalam pusaran narkoba. Mereka bahkan tidak mengenal narkoba sebelumnya. Dari pemeriksaan pula diketahui bahwa salah satu caranya, anak calon korban sering diberi minuman yang ternyata dalam minuman tersebut dicampuri dengan pil koplo. Dengan campuran tersebut, korban akan merasakan efek meminum pil penenang. Kadarnya terus ditambah setiap kali memberi minuman. Dengan begitu, efek pil tersebut semakin besar sehingga membuat anak mudah untuk kecanduan dan mengalami ketergantungan. Bandar baru mereguk kesuksesan ketika anak mengalami ketergantungan. Setelah itu, barulah naik ke tahap selanjutnya yakni pengenalan zat baru misalnya sabu-sabu. Bandar dengan mudah menyuruhnya mengirim narkoba. Tugas yang dibebankannya digambarkan dengan cukup sederhana. Anak disuruh mengambil narkoba di tempat tertentu, membawa, dan meletakkannya di tempat yang ditentukan. Setelah itu, anak mendapat imbalan narkoba.

Data Satresnarkoba Polrestabes Surabaya sampai pada kwartal ketiga tahun 2018 total ada 20 orang tersangka dengan anak sebagai kurir narkoba. 
Jumlah tersebut 15 orang tetapkan sebagai pemakai, 2 pengedar dan 3 kurir. Dari 3 orang kurir narkoba tersebut 1 anak berstatus pelajar dan 2 orang putus sekolah. Imbalan yang diterima kurir tersebut adalah mendapatkan 1 gram sabu sabu dan uang Rp. 200.000,-. Jelas disini anak sebagai kurir narkoba tersebut juga ternyata sudah kecanduan narkoba yakni dengan diberikannya imbalan sabu-sabu. Dan juga disini juga diketahui bahwa anak anak tersebut bukan dari golongan mampu secara finansial. Dengan hanya diberikan nominal Rp. 200.000,- mereka mau melakukan pekerjaan beresiko tinggi.

Kasus lain terjadi pada akhir Tahun 2018 yakni sekitar pukul 16.00 WIB. Saat itu Anggota Satlantas Polrestabes Surabaya yang bertugas mengatur lalu-lintas di depan Hotel Mercure, menerima pengaduan dari seorang ibu-ibu yang mengaku mendapat informasi lewat pesan BBM dari Putrinya FN yang mengatakan dirinya tengah di sekap di Wisma Leces Jl. Cimanuk No. 29-31 Surabaya.

5 "Mensos: anak-anak diincar jadi kurir narkoba" http://www.antaranews.com/berita/569885/mensos-anak-anakdiincar-jadi-kurir-narkoba. diakses tanggal 7 Februari 2018.

6 "Anak Dibawah Umur Rentan Jadi Kurir Narkoba", http://gosulses.com/news/20/08/2016/anakdi-bawah-umurjadi-rentan-jadi-kurir-narkoba/, diakses tanggal 7 Februari 2019

Menanggapi laporan ibu-ibu tersebut, sekitar pukul 16.30 WIB Anggota Satlantas Polrestabes Surabaya bersama orang tua dari FN berangkat menuju Wisma Leces di J1. Cimanuk No. 29-31 Surabaya. Sesampainya di lokasi Petugas Satlantas Polrestabes Surabaya mengkonfirmasikan kepada petugas keamanan Wisma tersebut, dan dikonfirmasi bahwa FN sudah berada di Wisma tersebut sejak tanggal 17 September 2016. Anggota Satlantas Polrestabes Surabaya berserta Orang tua kemudian melakukan pengecekan dan penggeledahan yang kemudian didapati Tersangka BS (26) warga Dukuh pakis. Di kamar tersebut juga didapati empat orang anak dibawah umur yang keseluruhannya berjenis kelamin perempuan dengan kisaran umur antara 16 sampai dengan 17 tahun Yakni, BL, DN, FN, dan DH. Dari hasil penyidikan yang dilakukan oleh Satresnarkoba diketahui bahwa keempat anak perempuan tersebut akan digunakan sebagai kurir oleh jaringan pengedar narkotika. Selama berada di wisma leces, mereka diberikan sabu yang cukup banyak pengakuan dari salah satu korban, bahwa dirinya diberi sampai 21 kali. Selanjutnya kasus ini dikembangan, Satresnarkoba menemukan ada beberapa anak lain yang sudah dibina menjadi kurir, tiga anak laki-laki yaitu FS, GK dan RF. Merurut pengakuan dari FS, dirinya telah mengirimkan barang lebih dari sepuluh kali.

Kejadian tersebut merupakan sedikit fenomena yang terungkap mengenai bagaimana anak dengan berbagai lemahnya kondisi psikis mereka yang oleh para bandar narkoba mereka dimanfaatkan menjadi kurir narkoba. Anak adalah generasi penerus yang akan datang. Baik buruknya masa depan bangsa tergantung pulapada baik buruknya kondisi anak saat ini. Anak sebagai sebuah pribadi yang sangat unik dan memiliki ciri yang khas. 
Walaupun dia dapat bertindak berdasarkan perasaan, pikiran dan kehendaknya sendiri, ternyata lingkungan sekitar mempunyai pengaruh yang cukup besar dalam membentuk perilaku seorang

anak. ${ }^{7}$ Seseorang yang menjadi kurir narkotika merupakan suatu rangkaian permufakatan jahat dalam menjalankan peredaran narkotika secara illegal, tetapi dalam kapasitas kategori anak yang menjadi kurir, ini merupakan satu hal yang begitu memprihatinkan dimana anak tersebut telah berhadapan dengan hukum dan tergolong telah melakukan tindak pidana narkotika.

\section{B. Metode}

Dalam Penelitian ini menggunakan pendekatan undang-undang (statute approach), dan pendekatan konseptual (conceptual approach). Jadi selain melakukan telaah terhadap Undangundang terkait permasalahan yang dibahas maka dalam peneliti juga menggunakan pendekatan konseptual, yakni perlunya merujuk pada prinsip-prinsip hukum.

\footnotetext{
${ }^{7}$ M. Nasir Djamil, Anak Bukan Untuk di Hukum, Sinar Grafika, Jakarta, 2013, hal. 11
}

Prinsip-prinsip ini dapat diketemukan dalam pandangan-pandangan sarjana melalui teori teori hukum ataupun doktrin-doktrin hokum.

\section{Pembahasan}

\section{Perekrutan Anak Sebagai Kurir Dalam Jaringan Peredaran Narkoba}

\subsection{Sistem Jaringan Narkoba}

Khoirun Hutapea di tahun 2011 dalam penelitiannya yang berjudul "Pola- pola Perekrutan dan Kegiatan Kurir dalam Trafficking Narkoba Jaringan Internasional" ${ }^{9}$, mengungkapkan bahwa kuatnya jaringan peredaran dan penyalahgunaan narkoba untuk membuat bisnis yang ada didalamnya tetap berjalan dan aman maka sindikat tersebut membentuk pos-pos dibawahnya, tanpa mereka (sesama pos) mengetahui satu sama lainnya, yang lebih dikenal sebagai "sistem sel". Sehingga melalui jaringan yang ada didalamnya dapat membentuk fungsi supply dan lingkaran setan perdagangan narkoba, juga menjadi penghubung utama bagi mata rantai selanjutnya dari sisi demand, yaitu penyalahgunaan. Karena hal tersebut penyalahgunaan narkoba ini sulit untuk ditembus karena merupakan sistem kejahatan yang cukup rapih.

Dalam hal ini menurut Hutapea, jaringan peredaran narkoba merupakan jaringan kerja di bawah tanah atau terlarang secara hukum, dan anggota-anggota jaringan narkoba menyadari betul mengenai 
posisi mereka itu. Karena itu, hubungan antara anggota-anggota adalah tertutup atau rahasia bagi orang yang bukan anggota jaringannya.

Hal yang diungkapkan oleh Hutapea tersebut juga ditemui oleh peneliti dalam observasi di lapangan, dimana pola permainan dari bandar memang tidak saling mengenal siap diatasnya. Sebagai contoh, di Lapas ada bandar narkoba yang masih aktif dan di Lapas yang sama ada Napi lain yang membuat Narkoba. Mereka tidak saling mengenal orangnya dan mereka punya kelompok-kelompok yang saling menutupi identitas masing-masing. Jadi masing-masing dari mereka punya perkumpulan mainnya sendiri, kelas pengedar sebatas kelas pengedar saja tidak sampai mengenai siapa pembuatnya, karena pembuatnya pola permainannya cuma ke sesama pembuat narkoba juga.

Sebuah jaringan peredaran narkoba dalam beroperasi terdiri dari sejumlah jaringan yang lebih kecil lagi dibagian bawahnya dengan bertambah banyak anggotanya. Anggota- anggota tersebut tidak saling mengenal terkecuali para aktor struktur yang diatasnya dapat mengetahui siapa aktor yang berada di bawah jaringannya.

\footnotetext{
${ }^{8}$ Peter Mahmud Marzuki, Penelitian Hukum, Kencana, Jakarta, 2009, hal.93

${ }^{9}$ Khoirun Hutapea, Pola-Pola Perekrutan, Penggunaan, dan Kegiatan Kurir dalam Jaringan Peredaran Narkoba Internasional. Tesis Jurusan Kriminologi, Universitas Indonesia, 2011.
}

Namun anggota-anggota jaringan tersebut tetap berbentuk jaringan kerja yang saling mempengaruhi serta saling menghubungkan jaringan-jaringan di dawahnya untuk memperlancar dan mengamani bisnis peredaran gelap narkoba ini. Pada bagian keseluruhannya yang paling diperlukan adalah para pengedar atau bandar, yang memperjual belikan barang ini dengan bantuan para kurir yang bergerak kesegala wilayah untuk menyebarkan kepada para konsumen dengan tetap kepada sistem sel yang dijelaskan di atas.

Fungsi dari kurir itu sebagai pengantar barang dari bandar yang memiliki barang dalam jumlah banyak kepada para bandar yang lebih kecil lagi di bawahnya. Faktor kesetiaan menjadi modal utama dalam bisnis ini karena semakin setia seseorang terhadap jaringan peredaran narkoba yang melibatkannya akan semakin besar kepercayaan yang diberikan oleh para anggota di atasnya yang berdampak dengan bertambah banyak barang narkoba yang diterimanya untuk dijualnya dan semakin terjamin keamanan dirinya dalam bisnis peredaran narkoba, bukan hanya untuk dirinya pribadi tetapi juga kepada keluarganya. Hal demikian sesuai dengan yang diungkapkan oleh Fukuyama dalam teorinya tentang modal sosial (social capital). Dimana secara sosiologis, kepercayaan (trust) merupakan suatu unsur utama dalam modal sosial untuk mendorong seseorang bekerjasama dengan orang lain untuk 
memunculkan aktivitas ataupun tindakan bersama yang produktif ${ }^{10}$ yang dalam hal ini melancarkan sistem jaringan peredaran narkoba dan meningkatkan modal sosial ekonominya berupa semakin banyaknya keuntungan yang diperolehnya dengan semakin banyaknya jumlah barang narkoba yang diedarkan yang diberikan dari sistem sel di atas kepada sistem sel yang dibawahnya.

Selain dua unsur utama dalam modal sosial tersebut, yaitu kepercayaan (trust) dan timbal balik (reciprocal) terdapat satu unsur lagi yang tidak kalah penting untuk menganalisis mengenai jaringan peredaran narkoba secara sosiologis dengan menggunakan teori dari Fukuyama. Unsur utama tersebut adalah interaksi sosial.

\footnotetext{
${ }^{10}$ Francis Fukuyama, Op.Cit., hal. Xii
}

\subsection{Faktor Penyebab Anak Menjadi Pengguna Narkoba}

Dari hasil wawancara penulis dengan Anggota Resnarkoba Polrestabes Surabaya, diperoleh keterangan bahwa beberapa faktor penyebab anak bisa terlibat dalam penyalahgunaan narkoba secara umum adalah sebagai berikut:

\subsubsection{Faktor Lingkungan}

Faktor lingkungan merupakan faktor utama penyebab terjadinya penyalahgunaan yang dilakukan oleh anak jalanan. Pertumbuhan dan pengembangan kepribadian bagi anak jalanan sangat dipengaruhi oleh daerah lingkungan sekitarnya. Keadaan lingkungan sekitar dapat meliputi teman-teman dalam pergaulan di jalanan maupun daerah tempat tinggalnya. ${ }^{11}$

\subsubsection{Faktor Keluarga}

Pada umumnya seorang anak dibesarkan oleh sebuah keluarga sampai pada tingkat dewasa. Di samping itu kenyataannya menunjukkan bahwa di dalam sebuah keluarga anak mendapatkan pendidikan pembinaan yang pertama kali. Keluarga adalah suatu kesatuan sosial 
yang terkecil yang terdiri atas suami, istri, dan jika ada anak-anak dan didahului oleh perkawinan. Keluarga merupakan lingkungan yang paling dekat dan terkuat dalam mendidik anak, terutama anak-anak yang belum sekolah. Dari keluargalah lahirnya manusiamanusia yang berkualitas atau yang tidak berkualitas. Dengan kata lain karakter atau kepribadian seseorang terbentuk oleh pola asuh yang diperolehnya sejak kecil. Hal itu karena fungsi keluarga sangat penting dalam pembinaan masyarakat. Dengan demikian seluk beluk kehidupan keluarga akan memiliki pengaruh yang sangat besar bagi perkembangan seorang anak.

\subsubsection{Faktor Keadaan Ekonomi}

Salah satu teori yang tertua diketahui oleh banyak orang adalah Divergent Theories, yang berarti bahwa kejahatan timbul karena kemiskinan. Plato (427- 347SM) mengemukakan bahwa di setiap negara dimana terdapat banyak orang miskin, dengan cara diam-diam terdapat

banyak penjahat, pelanggar agama dan penjahat dari bermacam-macam corak termasukjuga pencuri/tukang copet. Aristoteles (384-322SM) juga mengatakan bahwa kemiskinan dapat menimbulkan kejahatan/pemberontakan.

Keadaan ekonomi pada dasarnya dapat dibedakan menjadi 2 (dua), yaitu keadaan ekonomi yang baik dan ekonomi yang kurang baik atau miskin.

\footnotetext{
${ }^{11}$ M. Taufik Makarao, Suhasril, dan H. M Zakky A.S, Tindak Pidana Narkotika, Ghalia Indonesia, Jakarta, 2005.

${ }^{12}$ H. M Ridwan dan Ediwarman, Asas-Asas Krimonologi, USU Perss, 1994, hal 81
}

Menurut Arrest, menyatakan bahwa orang-orang hukuman dan orang-orang yang terlibat kepada perbuatan jahat adalah sebagian besar berasal dari orang-orang yang ekonominya lemah sebagai akibat lingkungan penduduk di dalam kelas tersebut dan mengakibatkan kejahatan orang dewasa dan kejahtan anak-anak. ${ }^{13}$ Hubungannya dengan narkotika, bagi orang-orang yang tergolong dalam ekonominya sulit dapat juga ikut mengetahui, menikmati tentang narkotika dan sebagainya, tetapi kemungkinannya lebih kecil dari pada mereka yang ekonominya cukup. ${ }^{14}$

\subsubsection{Faktor Pendidikan}

Sekolah memegang peranan penting dalam melatih anak-anak untuk kehidupan selanjutnya. Kejahatan sering dilambangkan karena pendidikan yang jelek atau kegagalan dalam sekolah juga dilambangkan kepada rumah yang jelek dan pendidikan famili yang miskin. ${ }^{15}$ Selain 
faktor minimnya faktor pengetahuan narkoba di sekolah, jika dilihat dari faktor pendidikan, maka juga disebabkan karena tidak tuntasnya si anak dalam menempuh pendidikan atau terjadi putus sekolah. Putus sekolah bisa memicu dan dipicu penggunaan narkoba pada anak. Dengan putus sekolah maka anak akan banyak bergaul pada lingkungan yang tidak baik dan pada akhirnya bisa menjerumuskannya pada narkoba. Putus sekolah juga bisa dipicu oleh penggunaan narkoba oleh anda yang ditandai dengan rendahnya minat dan kemasalan anak untuk sekolah. ${ }^{16}$ Dengan tidak bersekolahnya anak, selain stigma negatif dari masyarakat maka semakin berkurang pula input positif pendidikan bagi otak anak sehingga semkin menjerumuskan anak dalam jaringan narkoba.

Jumlah anak yang berkonflik dengan hukum akibat terjeat narkoba dengan status pendidikan putus sekolah yang ditangani Saternarkoba PolrestabesSurabaya dipaparkan sebagai berikut :

\section{Tabel 1}

Status Pendidikan Anak Yang Terlibat Narkoba

\begin{tabular}{|c|c|c|c|}
\hline TAHUN & JUMLAH & PELAJAR & PUTUS \\
\hline 201 & 4 & 3 & 1 \\
\hline 201 & 8 & 5 & 3 \\
\hline 201 & 20 & 14 & 6 \\
\hline
\end{tabular}

Sumber : Data Sekunder Satresnarkoba Polrestabes Surabaya, 2019

\footnotetext{
${ }^{13}$ Edwin H. Sutherland, Asas-Asas Krimonologi, Alumni, Bandung, 1969, Hal 266

${ }^{14}$ Moh. Taufik Makaro, Drs. Suhasril, H. Moh Zakky A.S., Tindak Pidana Narkotika, Ghalia Indonesia, Bogor, 2005 , hal 54.

${ }^{15}$ Edwin H. Sutherland, Op.Cit., Hal 274.

${ }^{16}$ Retno Wibowo, dkk. Cerdas Hadapi Narkoba, Direktorat Pembinaan Pendidikan Keluarga Direktorat Jenderal

Pendidikan Anak Usia Dini dan Pendidikan Masyarakat Kementerian Pendidikan dan Kebudayaan, Jakarta, 2018 , hal. 23
}

Dari data diatas diketahui bahwa di tahun 2018 dari 20 tersangka narkoba yang masih berusia anak 30\% adalah anak dengan status pendidikan putus sekolah. Di tahun 2017 terdapat $37.5 \%$ tersangka anak dengan status putus sekolah dan $25 \%$ jumlah total anak putus sekolah di tahun 2016.

\subsection{Pola Perekrutan Anak Menjadi Kurir Narkoba}

Realitas saat ini adalah anak-anak bukan hanya terlibat sebagai pengguna dan kurir tetapi juga sebagai pengedar bahkan bisa termasuk dalam golongan bandar narkoba. Memang pada 
dasarnya para bandar besar yang berada di lapisan golongan atas tidak akan mau menjadikan anak-

anak sebagai bandar atau bagian anggota sindikat peredaran narkoba. Berdasarkan hasil penelitian penulis, memang terdapat permainan halus yang mereka mainkan untuk mendapatkan keuntungan dari barang produksi yang mereka edarkan dengan keterlibatan anak-anak di dalamnya. Tahap pertama mereka adalah membuat anak-anak kecanduan kepada narkoba sampai kepada tahap "selalu butuh", dan dengan sendirinya pasti para anak-anak tersebut akan mencari barang yang mereka butuhkan tersebut. Pada barang narkoba jenis shabu contohnya, tahap awal memang paket berukuran kecil senilai Rp.225.000 cukup untuk mereka pakai ramai-ramai atau paket hemat shabu senilai Rp.100.000 untuk konsumsi sendiri. Namun semakin lama akan semakin banyak lagi konsumsi barang yang mereka ingini, contohnya pada tahap ini paket senilai Rp.225.000 hanya untuk mereka pakai sendiri tidak lagi secara kolektifan menggunakan uang mereka untu mereka pakai secara beramai-ramai. Perlu diketahui satu paket berukuran kecil shabu senilai Rp.225.000 tersebut hanya bisa dipakai 3 kali pembakaran atau selama satu hari saja. Sehingga semakin jumlah dosis pemakaian meningkat maka nominal uang yang harus dikeluarkan adalah semakin besar. Bagi seorang anak, menjadi kurir narkoba dengan imbalan narkoba adalah jalan terbaik untuk mendapatkan sesuai dosis kebutuhannya. Hal inilah awal pintu masuk seorang anak menjadi kurir narkoba yang akan dengan mudahnya dikontrol oleh para pengedar.

Menurut Penulis, eksploitasi anak dengan menjadikan anak sebagai kurir, pengedar, maupun bandar Narkoba merupakan suatu

kejahatan yang dapat termasuk kedalam kasus perdagangan orang (Human Trafficking). Khusus korban anak cukup melihat dari serangkaian langkah proses tertentu untuk tujuan tertentu tanpa menyertakan atau ditentukan oleh cara (Korban anak = Proses + Tujuan). Secara ringkasnya manusia yang masih berusia di bawah 18 tahun merupakan tergolong usia anak-anak dan tidak boleh direkrut, ditampung, atau diterima bekerja dalam bentuk apapun. Apabila didapati

memanfaatkan jasa anak-anak dalam suatu pekerjaan maka hal tersebut tergolong ke dalam tujuan untuk mengeksploitasi anak, dimana eksploitasi anak tergolong ke dalam kasus perdagangan Orang (Human Trafficking) sebagai diatur dalam Pasal 2 Undang-undang Nomor 21 Tahun 2007 tentang Tindak Pidana Perdagangan Orang (UU TPPO).

2. Upaya Satresnarkoba Polrestabes Surabaya Dalam Menanggulangi Kegiatan Perekrutan Anak Sebagai Kurir Narkoba 


\subsection{Penanganan Anak Yang Berhadapan yang Berkonflik Dengan Hukum Sebagai} Kurir Narkoba

Sesuai data yang tercatat di Badan Narkotika Nasional Kota(BNNK) Surabaya, yang mana tiap tahunnya selalu terjadi peningkatanpengguna narkoba khususnya dikalangan pelajar yang notabene secara yuridis rata-rata masih tergolong usia anak (dibawah 18 tahun). Pada tahun 2016, tercatat sebanyak 84 pelajar di Surabaya menjadi pengguna narkoba dan menjalani rehabilitasi. Jumlah tersebut mengalami peningkatan di 2017. Yakni ada sebanyak 101 pelajar yang kecanduan narkoba. Rinciannya, ada 4 pelajar SD, 63 anak duduk di SMP dan 34 anak pelajar SMA. Dari data BNNK sebagian besar yang dikonsumi pelajar itu pil dobel L dan narkoba jenis sabu. Para pecandu di tingkat pelajar ini, sebagian besar pengguna pemula. $^{17}$

Sebagian dari pengguna narkoba tersebut akhirnya berurusan dengan hukum dan statusnya menjadi anak yang berkonflik dengan hukum. Sebagaimana Pasal 1 ayat 3 Undang-undang Sistem Peradilan

Pidana Anak (UU SPPA), mendefinisikan anak yang berkonflik dengan hukum sebagai anak yang sudah mencapai usia 12 (dua belas) tahun tetapi belum berumur 18 (delapan belas) tahun yang diduga melakukan tindak pidana. Anak-anak yang yang berkonflik dengan hukum dalam kasus narkoba ini setelah dilakukan penyidikan lebih lanjut oleh Satresnarkoba Polrestabes Surabaya ternyata memiliki peran yang berbeda-beda, mulai dari kurir, pengedar dan pemakai. Mengenai hal ini dipaparkan berikut :

Tabel 2

Peran Anak-Anak Yang Terlibat Dalam Penyalahgunaan Narkoba

\begin{tabular}{|c|c|c|c|c|}
\hline TAHU & JUMLAH & KURI & PENGED & PEMAKA \\
\hline 2016 & 4 & - & 1 & 3 \\
\hline 2017 & 8 & - & - & 8 \\
\hline 2018 & 20 & 3 & 2 & 15 \\
\hline
\end{tabular}

\footnotetext{
${ }^{17}$ Data Sekunder BNNK Kota Surabaya mengenai Penyalahgunaan Narkoba di Kalangan Pelajar Tahun 2018 Sumber : Data Sekunder Satresnarkoba Polrestabes Surabaya Tahun 2019
}

\subsection{Upaya Penanggulangan Perekrutan Anak Sebagai Kurir} Narkoba 
Penanggulangan penyalahgunaan narkoba khususnya dalam penanggulangan kegiatan perekrutan anak menjadi kurir narkoba secara garis besar dikelompokkan menjadi tiga kegiatan utama mulai dari upaya

pre-emtif, preventif, represif, serta secara berkesinambungan

\subsubsection{Upaya Penanggulangan Secara Preemtif}

Upaya preemtif adalah upaya pencegahan yang dilakukan secara dini, antara lain mencakup pelaksanaan kegiatan koordinasi, kaderisasi serta penyuluhan yang bersifat dengan sasaran untuk memengaruhi faktor-faktor penyebab pendorong dan faktor peluang (Faktor Korelatif Kriminogen) dari adanya kejahatan tersebut, sehingga akan tercipta suatu kondisi kesadaran kewaspadaan dan daya tangkal serta terbina dan terciptanya kondisi perilaku dan norma hidup bebas dari segala ancaman narkoba khususnya bagi anak.

\subsubsection{Upaya Penanggulangan Secara Preventif}

Kepolisian Resor Kota Besar Surabaya khususnya satuan reserse narkoba juga melakukan upaya preventif. Adapun upaya preventif adalah upaya pencegahan dengan melakukan pengawasan dan pengendalian peredaran narkoba untuk mencegah terjadinya peredaran gelap dan penyalahggunaan narkoba yang pada akhirnya akan mencegah terjeratnya anak dalam jaringan narkoba khususnya sebagai kurir narkoba.

\subsubsection{Upaya Penanggulangan Secara Represif}

Usaha penangulangan tindak pidana penyalahgunaan narkoba secara represif, juga merupakan usaha pengangulangan kejahatan dengan hukum pidana yang pada hakekatnya merupakan bagian dari usaha pencegahan hukum oleh karena itu sering pula dikatakan, bahwa politik dan kebijakan hukum pidana juga yang merupakan bagian dari penegakan hukum. Upaya represif penyalahguna narkotika merupakan upaya penindakan dan penegakan hukum terhadap ancaman faktual dengan sanksi tegas dan konsisten dapat membuat jera terhadap para pelaku penyalahgunaan dan pengedar narkotika.

\section{Kesimpulan}

1. Terjerumusnya anak dalam penyalahgunaan narkoba diakibatkan karena factor lingkungan khususnya dikarenakan salah pergaulan. Faktor keluarga juga turut mempengaruhi anak terjerumus dalam narkoba karena ketidakharmonisan keluarga dan ketidakperhatian orang tua. Selain itu kemiskinan sebagai factor ekonomi dan rendahnya tingkat pendidikan serta kurangnya pendidikan narkoba di sekolah turut andil menyebabkan anak terjerumus dalam narkoba. Mudahnya anak dibujuk dengan upah yang rendah, ditambah kondisi emosional 
anak yang tidak stabil karena masuk masa pencarian jati diri serta minimnya kecurigaan orang lain pada anak ketika membawa narkoba membuat para bandar dan pengedar tertarik menjadikan anak sebagai kurir narkoba. Pola rekrutmen yang dilakukan untuk menjadikan anak sebagai kurir narkoba adalah melalui pemanfaatan lemahnya kondisi ekonomi anak dan ketidakmampuan anak untuk bekerja sehingga anak tidak ada jalan lain mendapatkan uang untuk narkoba selain menjadi kurir. Pemanfaatan loyanlitas anak pada rekan sekelompoknya, penggunaan pola jebakan dan ancaman merupakan cara lain dalam merekrut anak dalam sindikat narkoba.

2. Sejak berlakunya UU SPPA, penyelesaian perkara pidana anak bisa diselesaikan melalui diversi, termasuk nak yang melakukan penyalahgunaan narkoba yang dalam kajian ini dijadikan sebagai kurir. Tersangka yang masih di bawah umur harus didampingi oleh kuasa hukum dan Bapas, mulai dari penyidikan hingga putusan pengadilan. Bapas dalam hal ini akan melakukan hasil penelitian kemasyarakatan terhadap anak yang hasil penelitian kemasyarakatan tersebut kemuian diserahkan pada Penyidik sebagai rekomendasi untuk melakukan diversi. Diversi hanya bisa dilakukan untuk anak yang melakukan ancaman pidana kurang dari 7 tahun. Walaupun mendapatkan diversi, untuk anak dengan ketergantungan narkoba wajib dilaksanakan rehabilitasi untuknya. Begitu pula dengan anak dengan tindakan penyalahgunaan narkoba dengan ancaman diatas 7 tahun, walaupun tidak ada diversi, anak tersebut tetap berhak mendapatkan rehabilitasi selama proses acara pidananya berlangsung. Upaya penanggulanganan perekrutan anak sebagai kurir narkoba oleh Satresnarkoba Polrestabes Surabaya dilakukan dengan cara preemtif yakni melalui koordinasi terpadu dengan BNN Kota Surabaya dengan pertukaran informasi mengenai anak yang terjerat narkoba beserta sindikat narkoba yang terdeteksi. Pembentukan kader pelajar anti narkoba serta penyuluhan narkoba pada orang tua siswa merupakan cara preemtif yang dilakukan oleh Satresnarkoba Polrestabes Surabaya. Sedangkan cara represif dilakukan dengan penerapan hukum acara pidana khususnya bagi para pengedar dan bandar narkoba untuk memutus jaringan narkoba. Tindakan tegas dan terukur serta berbagai operasi penggerebekan narkoba diharapkan dapat memutus rantai peredaran narkoba khususnya yang menyasar anak untuk

dijadikan

kurir. 
Buku

\section{Bibliography}

Alabnese, Jay. Kejahatan Terorganisasi (Organized Crime) Akar dan Perkembanganannya, renadamedia Group, 2016.

Data BNN Provinsi Jatim 2016.

Data Sekunder BNNK Kota Surabaya mengenai Penyalahgunaan Narkoba di Kalangan Pelajar Tahun 2018

Djamil, M. Nasir. Anak Bukan Untuk di Hukum, Sinar Grafika, Jakarta,2013.

Fukuyama, Francis. Op.Cit.,

Hutapea, Khoirun. Pola-Pola Perekrutan, Penggunaan, dan KegiatanKurir dalam Jaringan Peredaran Narkoba Internasional. Tesis Jurusan Kriminologi, Universitas Indonesia, 2011.

Ilham, Bisri. Sistem Hukum Indonesia, Grafindo Persada, Jakarta, 2004. Makarao, H. M. dan Ediwarman, Asas-Asas Krimonologi, USU Perss, 1994.

Makaro, Moh. Taufik, Drs. Suhasril, H. Moh Zakky A.S., Tindak Pidana Narkotika, Ghalia Indonesia, Bogor, 2005.

Makarao, M. Taufik., Suhasril, dan H. M Zakky A.S, Tindak Pidana Narkotika, Ghalia Indonesia, Jakarta, 2005.

Marzuki, Peter Mahmud. Penelitian Hukum, Kencana, Jakarta, 2009. Sutherland,, Edwin H Asas-Asas Krimonologi, Alumni, Bandung, 1969. Sutherland, Edwin H. Op.Cit.

Wibowo, Retno, dkk. Cerdas Hadapi Narkoba, Direktorat Pembinaan Pendidikan Keluarga Direktorat Jenderal Pendidikan Anak Usia Dini dan Pendidikan Masyarakat Kemeterian Pendidikan dan Kebudayaan, Jakarta, 2018.

Internet

"Anak Dibawah Umur Rentan Jadi Kurir Narkoba", http://gosulsel.com/news/20/08/2016/anak-di-bawah-umur-rentan-jadi-kurir-narkoba/, diakses tanggal 9 Februari 2019

"Mensos: anak-anak diincar jadi kurir narkoba" http://www.ntaranews.com/berita/569885/mensos-anak-anak-diincar-jadi-kurir-narkoba, diakses tanggal 9 Februari 2019 